\title{
Being an Ethical Speaker Online: Correspondence with Foreign Partners
}

\author{
Elena V. Osetrova* \\ Krasnoyarsk State Pedagogical University \\ named after V.P. Astafiev \\ 89 Ada Lebedeva Str., Krasnoyarsk, 660049, Russia
}

Received 28.08.2015, received in revised form 29.09.2015, accepted 06.10.2015

Analysis of the rules of language behavior in social network "VKontakte" is represented in the paper. 14 rules in total constitute the unwritten code (the term of T.V. Shmeleva): "Do not tell what is unpleasant for the interlocutor", "Do not exaggerate", "Follow the same speech manner" etc.

It was found that the work of each rule follows a specific mechanism: every time it 1) is activated in a particular communicative mode (following, prevention or breaking the rule), 2) is done in accordance with a specific model (standard, extended and reduced) and 3) has a series of linguistic markers. More than 500 participants of the international society of the Internet community (social network "Vkontakte") prove that the Rules implementation is specific, depends on the circumstances of live dialogue in "Vkontakte" network, and the general purpose of language training. Firstly, presence of evaluative expressions commenting on verbal skills of the interlocutors, and secondly, active functioning of the rules "Give information that contain well-known to the listener" and "Do not tell what is commonly known and banal" are meant. They are regularly used not only to maintain social contact, but that is the most important for language training - for natural, extended in time language mastering, corresponding with the principles of Lifelong Learning.

Supposing that the reconstructed mechanism of the Rules functioning is universal in general, it can be used as a matrix, "applied" to one or another communicative situation and getting new useful results.

Keywords: rules of language behaviour; internet communication; communication mode; model; language marker; language training.

DOI: 10.17516/1997-1370-2015-8-11-2561-2571.

Research area: pedagogy, philology.

\section{Introduction}

The rules of language behavior are a subject introduced in Russian linguistics by Y.V. Rozhdestvensky in the $70 \mathrm{~s}$ of the $20^{\text {th }}$ century within general philology theory (Rozhdestvensky, 1979. p. 20-39;
Rozhdestvensky, 1996. p. 34-46, 51-62). In 1983 T.V. Shmeleva started studying this subject (Shmeleva, 1983; Shmeleva, 1995); the researcher introduced the rules in the form of the so-called Code of language behavior, which includes three sections:

(C) Siberian Federal University. All rights reserved

* Corresponding author E-mail address: osetrova@yandex.ru 
A) rules in the interests of the listener that have the maximum strength and relate to the statement content:

1. Give information that contain wellknown to the listener.

2. Give information that doesn't differ from the everyday logic of the listener and his ideas about the ordinary course of events.

3. Do not tell what is commonly known and banal.

4. Do not tell what is unpleasant for the interlocutor, when possible tell what is pleasant [hereinafter additions to the definitions in italics are made by the author. - E.O.].

5. Speak specifically, trying to find the only right words, and fully, avoiding understatements.

6. Stick to one method of conversation and one genre; define changing a topic or a style.

7. Do not be categorical;

Б) rules in the interests of the speaker, also relating to the statement content:

8. Be sincere and truthful.

9. Do not be too outspoken.

10. Do not exaggerate.

B) requirements for the selection of linguistic means:

11. Do not use the linguistic forms that may not be known to the listener.

12. Speak in accordance with the norm and as is customary; including, have a conversation in a normal average pace.

13. Avoid clichés.

14. Choose words and expressions according to the nominative habits: a) your own, b) the listener and c) according to the subject of speech.

At that, each of the rules marks certain language formulas. Thus, a marker of the $4^{\text {th }}$ rule is the phrase I'm afraid to hurt you, but ..., markers of the $8^{\text {th }}$ rule are phrases to be honest, to be frank; frankly speaking, and a marker of the $12^{\text {th }}$ is expression if I may say so and call it differently ...

The rules of language behavior are focused on a communicative standard (Kliuev, 2002, p. 17-18). They specify well known in linguistic pragmatics principles (cooperation, courtesy) and the category of language communication (Quantity, Quality, Relation, Manner) mentioned by G.P. Grice and G. Leech. The latter, in turn, provide communications in general and are recognized as universal (Grice, 1975; Leech, 1983; see also: Gordon, Lakoff, 1975; Clyne, 1994).

It is obvious, however, that in every national group or a typical dialogue situation rules work specifically. That is why a person who decided to study a foreign language, in addition to its sound system, vocabulary and grammar, should also master these unwritten rules. By becoming a part of language learning such as Lifelong Learning, orientations on effective communication can not be mastered in the course of one or two lessons but require active practice and long time.

These circumstances have allowed the author to formulate the subject of the research paper, asking a question how the Code of language behavior is applied in online social networks, under circumstances where the Russian language is used as a single code in foreign students' communication and in their dialogue with the Russian-speaking partners.

To be more specific, we are interested in the mechanism of the rules functioning. The material for study was more than 500 dialogues of the users of social network "VKontakte", collected in $2013-2015$.

Thus, what have the analysis the collected data base shown? 


\section{Modes of the Rules Functioning}

Communicative activity of representatives of different cultural and linguistic traditions not only has similar features, but differences as well, concerning style, manner of interaction and language behavior in the similar situations. All this must be taken into account to ensure effective cross-cultural communication. If the specific is ignored, we will inevitably fail in communication, moreover, we face a full-fledged conflict.

In the course of analysis three communication modes that activate the Code and provide following the language rules were identified: following, prevention and breaking, what is depicted in the Fig. in the form of conditional overlapping zones (Fig. 1).

The content of regulatory following or breaking of one or another rule does not cause additional problems, but the essence of its prevention should be clarified.

Prevention is understood as those cases when the speaker is aware that he/she is risking to violate a norm of verbal communication and is signaling about this, warning the addressee; see the example of prevention the rule "Stick to one method of conversation and one genre; define changing ... a style":

$\begin{array}{ll}\text { Russian original } & \text { English translation } \\ \text { [переписка китайского } & \text { [communication of a } \\ \begin{array}{l}\text { студента (А) и его } \\ \text { знакомой - }\end{array} & \text { Chinese student (A) and } \\ \text { his acquaintance - a }\end{array}$

жительницы Красноярска (В)] dweller of Krasnoyarsk (B)] A: я иду учиться чтобы A: I'm going studying хорошо знать русский to know the Russian язык (чтобы дружиться language well (to friend с русской девушкой a Russian girl ha-ha-ha хаха это шутка) it's a joke) B: шутник $=) \quad$ B: joker $=$

Cases of normative use of the rules of language behavior and their breakings will be illustrated by fragments from other dialogues; compare following the rule "Be sincere and truthful":

Russian original

[переписка двух подруг]

$\mathrm{X:} \mathrm{у} \mathrm{тебя} \mathrm{как} \mathrm{дела?}$

Y: Хорошо, сегодня много работала и училась :)) ) было почто 4 часа философии... С приходом весны все сложнее сидеть на ней ;)))

\section{English translation}

[communication of two friends]

$\mathrm{X}$ : how are you?

Y: Fine, have been working and studying a lot today :)) ) there was almot 4 hours of Philosophy... With the coming of spring it is getting more and more difficult to sit through it ;)))

- and breaking the rule "Give information that doesn't differ from the everyday logic of the listener and his ideas about the ordinary course of events":
Russian original

[переписка

жительницы

Красноярска (C) и
English translation

[communication of a dweller of Krasnoyarsk (C) and a Chinese

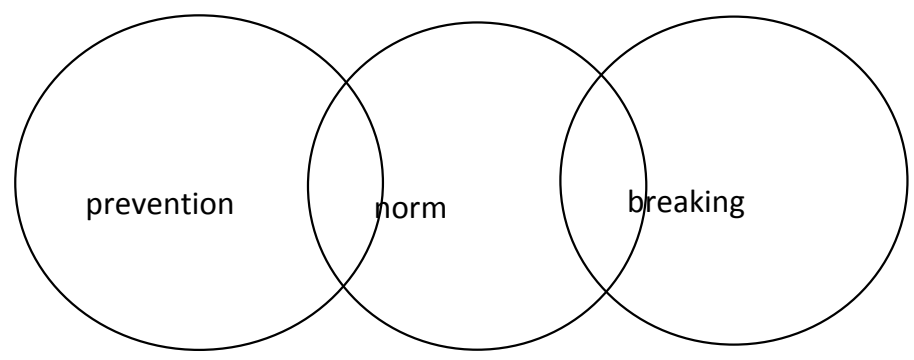

Fig. 1 
студента-китайца (D)] C: Мой брат в армии в чите. пишу ему письмо.

D: Почему ты пишешь ему письмо? Почему ты не позвонила ему? <...>

$\mathrm{C}:$ Нет, это дороже. и в армии нет телефонов. лучше писать письмо. так принято у нас. $\mathrm{D}$ : хаха когда у меня есть [появился] ноутбук $<\ldots>$ g даже забыл как писать письмо. student (D)]

$\mathrm{C}$ : My brother is in army in chita. I'm writing a

letter to him.

D: Why are you writing a letter to him? Why didn't you call him? $<\ldots>$ $\mathrm{C}$ : No, it is more expensive. and there are no telephones in the army. it is better to write a letter. this is the way the things are done here.

D: haha when I have [got] the laptop $<\ldots>$ I have even forgotten how to write a letter.

\section{Communication Models} of the Rules

It was found out that use of a particular rule in online dialogues follows a certain communication model. And the models of following, breakings and prevention the rules are different.

Let us begin with the fact that following the rules of language behavior, by definition, is the most favorable mode of all of the abovementioned. Since intercommunication within its boundaries is without conflict, linguistic consciousness does not see the need for any specific reactions. A standard linguistic characteristic of such dialogues is only positive assessment of the successful speech act and/or reliable information; for example:
Russian original English translation

$\mathrm{X:} \mathrm{Гриша,} \mathrm{добрый}$ вечер! Передайте, пожалуйста, ребятам из своей группы и группы"Б”, что мы завтра учимся не с $\underline{10.20}, \underline{\text { a c } 12.30}$

Z: Хорошо ;

А.: а твоя папа водитель / он водил машину и везти леса в Китаю.

$\mathrm{X}$ : Grisha, good evening! Could you, please, tell your groupmates and students from group " $\mathrm{B}$ " that tomorrow we will study not from 10.20 , but from 12.30 Z: $\mathrm{OK}$;

A: and your father driver/ he drew car and to transport forests to China

В: да ) ого, запомнил.

B: yes ) wow, you have remembered.

The model of following the rules of language behavior as a result has the simplest explication, including the following common stages (Fig. 2).

The model of prevention, compared to the previous one is changed in its content at the initial stages, as the speaker is busy with excuses due to forced breaking of the Code (Fig. 3).

This is how it looks in relation to the rule "Do not tell what is commonly known and banal", where each of the communication stages is indicated in square brackets:

Russian original English translation

А: у нас новый год было 2 февраля, уже прошло, мы пели, танцевали)

A: we has New Year celebration on 2 of February, it passed, we sang, danced) not so

[Normative dialogue development]

Following the rules (author)

Reaction to following (addressee)

Continuation of communication (addressee and/or author)

Fig. 2 
[Forecasting of breaking the rule of language behavior]

$\downarrow$

Prevention of breaking (author)

$\downarrow$

Reaction to prevention (addressee)

Continuation of communication (addressee and/or author)

[including signal for continuation of communication]

Fig. 3

не так интересно [профилактика нарушения]. B: но Митя, если вы пели и танцевали, я думаю, это должно было быть весело)) [реакция на профилактику]

A: Да, для других, конечно. Очень интересно. Просто новый год <...> мне не так [по]нравился [продолжение общения].

The effect, achieved from prevention is obvious: warning about the introduction of the commonly known information (not so interesting), the speaker as if apologizes to the addressee and prepares his favorable perception. As a consequence, the latter even gets involved in the dialogue on the common topic, and a little bit later "justifies" the banality, complementing it with positive evaluation (it should have been fun)) ).

Finally, the model of breaking is the largest, as in order to correct a communicative mistake that has already been made, it is necessary to spend specific time and language resources (Fig. 4).

As an illustration we show the dialogue, there a participant breaks the rule "Do not use the linguistic forms that may not be known to the listener".

Russian original English translation

[переписка кореянки [communication of (К) и итальянца (И) - a Korean (K) and an слушателей курсов Italian (I) - participants русского языка - после of the Russian language отъезда кореянки на course - after the Korean родину] went to her country]

И: что делаете лето? I: what do summer? Do Куда-нибудь едете? you go anywhere? K: на следующий $\quad \mathrm{K}$ : in next Monday I'm понедельник я поеду going to Jeju island ) остров Дже джу) [breaking the rule - use [нарушение правила - of an unknown word] использование неизвестного слова] I: Jeju? Funny))) A И: Дже джу? Смешно))) Красивое место? [реакция на нарушение]

К: дже джу) это корейский язык) [ликвидация нарушения] да) очень красивый) и известное место для инностраннов) [иностранцев] beautiful place?_[reaction to breaking]

$\mathrm{K}$ : Jeju ) it is the Korean language ) [liquidation of breaking] Yes ) very beautiful and famous place for foreignors ) [foreigners]

I: It is absolutely necessary that I come [continuation of И: Нужно обязательно communication] что я при(е)ду!! [продолжение общения].
At the same time, it is obvious that from the part of the recipient breaking the rule caused the 
[Reasons for breaking the rules of language behavior, including agitated emotional state, insufficient experience in communication, manipulation]

Breaking the rule (author)<smiles>[AlH]</smiles>

Reaction to breaking (addressee)

Liquidation of breaking (author)

Continuation of communication (addressee and/or author)

[including signal of revived communication]

Fig. 4

effect of a kind of confusion (Funny)))), and then curiosity (Beautiful place?).

The identified models of the rules functioning represent a standard that in the daily practice of communication is often transformed. These changes can have two directions - expansion and reduction of models.

Expansion of model is observed when a brief statement at the stage of "liquidation of breaking" suddenly expands to an extensive commentary. This is what happens in the dialogue below, where the interlocutor is given obviously unpleasant evaluation, ignoring one of the speech norms.

Russian original

English translation

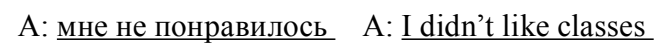
в вашей группе занятие in your group [breaking [нарушение правила] the rule] $\mathrm{B}$ : почему? [реакция на $\mathrm{B}$ : why? [reaction to нарушение] breaking]

A: Вы плохо готовитесь A: You get ready badly $<\ldots>$ я была часто у вас < ..> I visited your на занятиях и видела, / что многие из вас плохо готовятся / или говорят что забыли // и много прогуливаете. // а знать лучше русский язык вы не стали - /

мне это не приятно.
// Вы говорите так же
плохо / как и когда
только приехали.
// Мне обидно, /
что вы [не] любите
говорить, / что вы
ленивые. // Когда мы
с Ариной вели у вас
историю - / нам было
неприятно, / когда нас
попросили рассказать
с самого начала
историю потому, /
что вы прогуливали.
// Вы не уважаете
нас как учителей /
[комментарий]

// You speak as badly / as when you came. // It is offensive for me / that you don't like to say / that you are lazy. // When Arina and I gave you History lessons / it was unpleasant / when were asked to start History from the beginning because / you skipped a lot. // You don't respect us as teachers / [commentary]

The utterance, designed to liquidate the breaking, is transformed in this case, into the commentary, which content itself justifies the breaking: the author who conducts classes for foreign students has serious complaints about the quality of their preparation. When in "informational cause" commenting that leads to speech disorder, not only the author, but addressee as well is involved, the commentary becomes even more extended discussion.

The second opportunity to expand communicative model is to introduce the stage of 
"request for the rules execution." We can not say that it is widely used in online dialogues, however, it appears time to time in the implementation of the majority of the Code items. We will give an example regarding the same formula "Do not tell what is unpleasant for the interlocutor":
Russian original

\begin{tabular}{|c|c|}
\hline $\begin{array}{l}\text { А: Я не очень хороший } \\
\text { учитель [?] [запрос на } \\
\text { исполнение] }\end{array}$ & $\begin{array}{l}\text { A: I'm not a very good } \\
\text { teacher [?] } \\
\text { [request for execution] }\end{array}$ \\
\hline 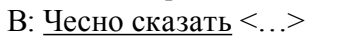 & B: To tell the tru $<\ldots>$ \\
\hline гы быстро говорила & you spoke Russian \\
\hline $\begin{array}{l}\text { русский язык. а как } \\
\text { сегодня говорила? } \\
\text { [исполнение - } \\
\text { профилактика] }\end{array}$ & $\begin{array}{l}\text { language fast. and how } \\
\text { did you speak today? } \\
\text { [execution - prevention] }\end{array}$ \\
\hline $\begin{array}{l}\text { А: не знаю..., нужно } \\
\text { спросить китайских } \\
\text { студентов. но ,они } \\
\text { вроде понимали }\end{array}$ & $\begin{array}{l}\text { A: I don't know ..., } \\
\text { you should ask Chinese } \\
\text { students. but they, sort } \\
\text { of, understood me }\end{array}$ \\
\hline $\begin{array}{l}\text { меня) [реакция на } \\
\text { профилактику] }\end{array}$ & $\overline{\text { [reaction to prevention] }}$ \\
\hline В: Понятно, сегодня & B: I understan \\
\hline$<\ldots>$ ты говорила очень & $<\ldots>$ you spoke very \\
\hline $\begin{array}{l}\text { ихий, ну это проблема } \\
\text { бсуждение]. }\end{array}$ & $\begin{array}{l}\text { quiet, but it a problem } \\
\text { [discussion]. }\end{array}$ \\
\hline
\end{tabular}

Reduction of the standard communication model, takes place in the case when one or several aforementioned stages are not implemented. This, in particular, happens when there was breaking of the rule that the addressee has not noticed or ignored.

\begin{tabular}{|c|c|}
\hline Russian original & English translation \\
\hline 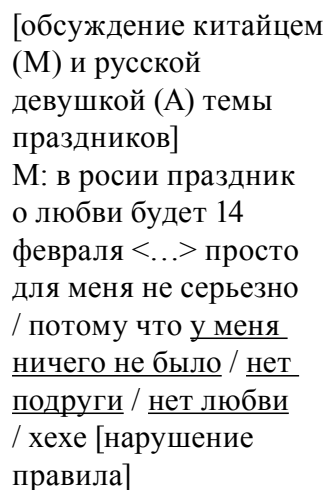 & $\begin{array}{l}\text { [discussion of the topic } \\
\text { of holidays between } \\
\text { a Chinese (M) and a } \\
\text { Russian girl (A)] } \\
\text { M: in russia the holiday } \\
\text { of love is on 14 February } \\
<\ldots>\text { not serious for me / } \\
\text { as I haven't had anything } \\
\text { / no girlfriend / no love/ } \\
\text { heh heh [breaking the } \\
\text { rule] }\end{array}$ \\
\hline
\end{tabular}
А: ну не знаю, / а мне нравятся такие праздники [продолжение общения].
It is indicative that the addressee prefers not to react to explicit breaking of the rule "Do not be too outspoken", avoiding the topic of personal relationships.

Reduction of models also usually takes place in relation to the rule "Speak in accordance with the norm and as is customary". Foreigners make a lot of mistakes when communicating in Russian. It is impossible to comment on each of them. Therefore, when the meaning of the message is generally clear, the addressee ignores grammar, spelling and punctuation mistakes, sacrificing them for a new piece of information.

\section{Conditionality of the Rules Functioning}

Understanding of the pragmatic content of the Rules can not be achieved without analysis of conditionality of their existence in the language.

If the general purpose of prevention of breaking of any of the Code postulates is single - taking care of communication comfort of the interlocutor - there are few conditions for breaking.

When the author consciously breaks a rule, it is possible to speak of deliberate influence, even manipulation that can be aimed at obscuring the true meaning of statements, reduction of the addressee status, and, finally, to conflict provocation.

However, errors in the Rules often have intentional nature, arising from the speaker's character, his/her emotional agitation or inexperience. Young age, belonging to another social, ethnic or linguistic culture become the "attributes of risk" resulting in work disruptions in interaction. The aforementioned causes of 
breakings are classified as accidental, arising in the space of natural unprepared communication. One of such spaces is social networks of the Internet.

As for the effects from the specific rule implementation, a lot depends on in which of the three aforementioned modes it is activated. In any case, here we refer to the "communication future" of dialogue and to the variants of its development.

The positive effect of compliance with the Code is, certainly, productive interaction of the dialogue participants, when particular situational problems are solved without conflict, and general purposes of communication (informing, influence, assessment and maintaining social contact) have been successfully achieved.

The total effect of speech violations prevention should be recognized as development of partnership relations and communicative tolerance. The consequence of this, in turn, will be speech problem overcoming (through the stage of "reaction to prevention"), and after that support / restoration of mutual understanding and effective continuation of the dialogue. If any of the participants show particular interest in what is happening, detailed discussion becomes the secondary effect of the speech problem.

The negative effects of the Code breakings should be recognized as different kinds of communication failures, defects and errors that can result in momentary or long-term interruption of dialogue, and furthermore, in conflict. Each separate failure should by quickly analyzed and eliminated, when possible, directly within the frames of the dialogue.

As for emotional states that accompany breakings of this kind, surprise, excitement, emotional distress, suspicion, resentment, anger, offence, fear; confusion, doubt and disbelief in information authenticity should be mentioned as mental ones.
To clarify the general picture of how the Code is used in practice, it was helpful to analyze the frequency of its rules. It was found out that in online dialogue it is very heterogeneous.

In the mode of prevention the rules in the addressee's interests become of key importance: "Give information that contain well-known to the listener", "Do not tell what is unpleasant for the interlocutor" and "Don't be too categorical" ( $9 \%$ in general). Their dominance is directly connected with the fact that international contact, when both parties remember them all the time:

- firstly, the fact that a lot in the ideas about another ethnic group and in the worldview of another language may be unknown/ unintelligible for the interlocutor (informational aspect),

- secondly, the fact that ideas about the norms of communication can also considerably vary in the various national groups, and hence, one should be extremely correct and careful within the frames of a particular speech situation (socio-verbal aspect).

The following rules are broken most often in the process of online communication between representatives of different national and language cultures:

- "Do not tell what is commonly known and banal" (8.8\%)

- "Speak specifically, trying to find the only right words, and fully, avoiding understatements" (9.8\%).

- "Speak in accordance with the norm and as is customary; including, have a conversation in a normal average pace" (8\%).

And finally, such rules as "Avoid clichés" and "Do not exaggerate" in our case turned out to be "irrelevant" orientations, which use is practically not marked by linguistic consciousness $(0.5 \%$ in general). Standard, and thus, not marked in any 
way and by anybody, implementation of the last rule is connected with the pursuit of international participants to convey factual information as accurately as possible in order to avoid being misunderstood. As for clichés, their separation from the language flow refers to the quite high level of competence, and, therefore, irrelevant to the foreign audience, which is at the primary level of language proficiency. The primary orientation in this case is to speak clear and understandable; understanding stylistic subtleties of language and language individuality acquisition are challenges of the future.

\section{Specific Features of Linguistic Implementation of Rules}

Specific features of linguistic implementation of the Rules are directly related to the fact that the Russian language, in our case, becomes not only a tool of international communication, but also the subject of education that should be mastered.

Specific feature is massive presence of evaluativewordsandexpressionsforcommentaries of online conversation participants. First of all, they concern with the use of language, in particular, the orientations to speak in accordance with the norm and as is customary.

$\begin{array}{ll}\text { Russian original } & \text { English translation } \\ \text { X: ты сейчас в } & \text { X: are you in } \\ \text { Красноярске? } & \text { Krasnoyarsk now? } \\ \text { Y: а нет уже вернулся, } & \text { Y: ah no, have already } \\ \text { щас в китае <..> } & \text { come back, in china } \\ \text { X: В Красноярск } & \text { now }<. .> \\ \text { приедешь? } & \text { X: Going to come to } \\ \text { Y: Дада но точное } & \text { Krasnoyarsk? } \\ \text { время пока я [не] могу } & \text { Y: Yesyes, but I can [not] } \\ \text { сказать } & \text { say the exact date yet } \\ \text { Х.: кстати / ты хорошо } & \text { X: by the way / you write } \\ \underline{\text { пишешь по русский! }} & \underline{\text { in Russian very well! }} \\ \text { Y: думаю да } & \text { Y: } \underline{\text { I think I do }} \\ \text { Х: ты молодец ) } & \text { X: well done ) }\end{array}$

Good confirmation of specific features is, in addition, mutual support of the rules "Give

information that contain well-known to the listener" (in the mode of maintenance) and "Do not tell what is commonly known and banal" (in the mode of breaking). Their complex works not only regarding basic development of social contact in each dialogue, but is regularly used for language and speech practice.

In this regard we will give an example of a typical breaking the rule "Do not tell what is commonly known" where stories a) about waiting for a friend who left, b) daily rest, c) food, and d) getting ready for the lesson, from informational position are quite excessive, but very useful for practicing action verbs, states, their tenses and modal forms.

\section{Russian original}

Г: что делаешь?

Д: ооо хахах я жду тебя когда ты вернешься из деревни. уже вернулась хорошо. надо отдыхать $\Gamma$ : да, ем сейчас $=$ ) а ты что делаешь?

Д.: да я тоже ем а мама тоже вернулась или домой?

$\Gamma$ : мама с сестрой уехали к себе домой )

Д: о ты любишь гулять вечером ?

$\Gamma:$ да, люблю.

Д: о хорошо я буду готовить урок .

\section{English translation}

G: what are you doing?

D: ooow! hahah I'm waiting for you when you come back from the village. already came back well. it is necessary to have rest G: yes, I'm eating now $=$ ) and what are you doing? D: I'm eating too and mom came back too or home?

G: mom and sister went home ) D: oh do you like evening walks? G: yes, I do. D: oh good I'm going to get ready for the lesson

\section{Results}

The major results of the research are as follows.

Three communication modes, within which the Code of language behavior functions, are identified: we called them "following", "prevention" and "breaking" the rules. For foreigners mastering the Russian language, the last two are of particular importance, as they 
make to focus on difficulties and give possibility to prevent errors.

Each of the modes of communication corresponds to the model of implementation. Thus, breaking the rule of language behavior involves elementary stages of "breaking itself $\rightarrow$ reaction to breaking $\rightarrow$ its liquidation $\rightarrow$ signal of revived communication". At that the standard model of rule is flexible, expanding or reducing depending on the dialogue circumstances.

The Rules functioning is connected with specific reasons, various effects, and, in addition, has specific linguistic marking.

Linguistic implementation of the rules is specific, following circumstances of the live dialogue in "VKontakte" and general educational context. Firstly, presence of evaluative expressions commenting on verbal skills of interlocutors, and secondly, active functioning of the rules "Give information that contain well-known to the listener" and "Do not tell what is commonly known and banal", are meant. They are regularly used not only for social contact maintenance, but, what is crucial, for the language training - for natural, extended in time language mastering, corresponding with the principles of Lifelong Learning.

Supposing that the reconstructed mechanism of the Rules functioning is universal in general, it can be used as a matrix, "applied" to one or another communicative situation and getting new useful results.

\section{References}

Clyne, M. Inter-cultural Communication at Work: Cultural Values in Discourse. Cambridge University Press, 1994.

Gordon, D. \& Lakoff, G. Conversational Postulates. Syntax and Semantics. V. 3. New York, San Francisco, London, Academic Press, 1975, p. 83 - 106.

Grice, H.P. Logic and Conversation, Syntax and Semantics. V. 3. New York, San Francisco, London, Academic Press, 1975, p. $41-58$.

Kliuev, E.V. Rechevaia kommunikatsiia: Uspeshnost' rechevogo vzaimodeistviia [Verbal Communication: Successfulness of Verbal Interaction]. Moscow, Ripol Klassik, 2002. 320 p.

Leech, G. Principles of Pragmatics. London, New York, Longman, 1983.

Rozhdestvensky, Y.V. Vvedenie v obshchuiu fililogogiiu [Introduction into General Philology]. Moscow, Vysshaia shkola, 1979. 224 p.

Rozhdestvensky, Y.V. Obshchaia fililogogiia [General Philology]. Moscow, New Millennium Fund, 1996. 326 p.

Shmeleva, T.V. (1983). Kodeks rechevogo povedeniia [The Code of Linguistic Behaviour]. Russian Language Abroad. 1, 72-77.

Shmeleva, T.V. Sub"ektivnye aspekty russkogo vyskazyvaniia [Subjective Aspects of the Russian Utterance]. Moscow, 1995. 35 p. 


\section{Правила речевого поведения}

\section{в сетевом сообществе:}

\section{переписка с участием иностранцев}

\section{Е.В. Осетрова}

Красноярский государственный педагогический университет им. В.П. Астафьева Россия, 660049, Красноярск, ул. Ады Лебедевой, 89

В статье представлен анализ правил речевого поведения в соииальной сети «ВКонтакте». 14 правил в совокупности формируют неписаный кодекс (термин Т.В. Шмелевой): «Не говори неприятности собеседнику», «Не преувеличивай», "Придерживайся одной речевой манеры» и др.

Выявлено, что работа каждого правила подчинена определенному механизму: всякий раз 1) активируется в том или ином коммуникативном режиме (соблюдение, профилактика или нарушение правила), 2) оформляется в соответствии с определенной моделью (стандартная, расширенная, редуцированная) и 3) имеет серию языковых маркеров. Более 500 диалогов участников интернационального интернет-сообщества (соииальная сеть "ВКонтакте») доказывают, что реализачия правил специфична, подчиняясь обстоятельствам живого диалога «ВКонтакте» и генеральной цели обучения языку. Имеются в виду, во-первых, присутствие оценочных выражений, комментирующих вербальные навыки собеседников, а во-вторых, активное функиионирование правил "Сообщай информацию, содержащую известное для слушателя» $и$ «Не сообщай общеизвестного, банального». Они регулярно используются не только для поддержки социального контакта, но, что принципиально важно, для речевой тренировки - для естественного, растянутого во времени освоения языка, согласованного с установками Lifelong Learning.

Если предположить, что реконструированный механизм функционирования правил в целом универсален, то его можно применять как матрииу, «накладывая» на ту или иную ситуаиию общения и получая новые полезные результаты.

Ключевые слова: правила речевого поведения, интернет-коммуникация, коммуникативный режим, модель, языковой маркер, обучение языку.

Научная специальность: 13.00.00 - педагогические науки, 10.00.00 - филологические науки. 